Johnson \& Wales University ScholarsArchive@JWU

2004

\title{
Affirmative Action: From Before Bakke to After Grutter
}

Peter Lehmuller

Johnson ఓ Wales University - Charlotte, plehmuller@jwu.edu

Dennis E. Gregory

Old Dominion University

Follow this and additional works at: https://scholarsarchive.jwu.edu/admin_publications

Part of the Education Commons, Public Affairs, Public Policy and Public Administration Commons, and the Sociology Commons

\section{Repository Citation}

Lehmuller, Peter and Gregory, Dennis E., "Affirmative Action: From Before Bakke to After Grutter" (2004). Administration Publications and Research. 1.

https://scholarsarchive.jwu.edu/admin_publications/1 


\title{
Affirmative Action: From Before Bakke to After Grutter
}

\author{
Peter Lehmuller \\ Dennis E. Gregory
}

Affirmative action as a policy to solve past racism has existed since the civil rights movement in the mid-twentieth century. Since its inception there has been controversy as to whether affirmative action can stand legal scrutiny. If it can, then under what circumstances and for what programs may it be used? Since the Bakke case in 1978, a variety of lower federal courts have sought to determine whether diversity is a compelling state interest in higher education admissions and other related programs, or whether race may even be used as a factor in admissions. The recent Grutter and Gratz cases have helped to clarify those issues, but they have left many questions to be answered by policy makers and the courts. Since the Grutter and Gratz decisions, new challenges have been raised to affirmative action. This article describes the history of affirmative action, describes the controversies and current status of the law with regard to public postsecondary institutions admissions policies, and raises several issues about which admissions and student affairs professionals in general should be concerned.

Peter Lehmuller is the dean of culinary education at Johnson and Wales University in Charlotte, North Carolina. Dennis E. Gregory is an associate professor of educational leadership and counseling at Old Dominion University in Norfolk, Virginia. 
The civil rights movement provided the impetus for vast changes in social policy that are reflected in many of the judicial, legislative, and executive activities of the federal government since the 1950s (Dixon, 1979; Hendrickson, 2001; Kaplin \& Lee, 1995; White, 2001). Board of Regents of the University of California v. Bakke (1978) is a landmark case involving affirmative action in higher education. In this decision, however, the Supreme Court did not provide a unanimous, clear decision; and the effects of the decision continue to impact higher education case law related to affirmative action.

Until the recent Supreme Court rulings in the University of Michigan (UM) cases (Grutter v. Bollinger et al. [2003] and Gratz et al. v. Bollinger et al. [2003]), Bakke was considered the benchmark against which other higher education affirmative action decisions were measured (Hendrickson, 2001; Kaplin \& Lee, 1995; White, 2001). Despite the lack of clarity in the original ruling, and the variety of ways Bakke has been interpreted subsequently by the courts, it is clear that it has served as the case from which all courts have sought guidance in higher education cases.

In both the Grutter and Gratz cases, Bakke faced its most serious challenge as legal precedent for affirmative action in college admissions. In hearing both Grutter and Gratz, the District Court arrived at opposite conclusions about affirmative action programs at UM. For institutions of higher education specifically, and for the legal system generally, these conflicting opinions brought into strong relief the necessity for the Supreme Court to provide clear guidance on this politically and socially charged issue. The Supreme Court ("the Court") used these cases to address affirmative action in admissions and to address issues raised by conflicting decisions in other lower courts. In doing so, the Court reaffirmed the view of Justice Lewis Powell in his Bakke opinion that the "attainment of a diverse student body. . . clearly is a constitutionally permissible goal for an institution of higher education" (438 US 265, 311). Both Justice O'Connor, writing for the Court in Grutter, and Chief Justice Rehnquist, writing for the Court in Gratz, concurred with Powell's finding that diversity is a compelling interest. In the compelling interest doctrine, race may be used as a factor (but not the only factor) in admissions decisions; and any use of race as a factor must survive strict scrutiny because, as Powell wrote, "(r)acial and ethnic distinctions of any sort are inherently suspect and thus call for the 
most exacting judicial examination" (438 US 265, 291). At the same time, Justice O'Connor noted that affirmative action plans such as those at the UM Law School could not last forever, requiring "sunset provisions" for current race-conscious admissions programs and "periodic review to determine whether racial preferences are still necessary" (539 US 306, 342).

This article will examine the development of the concept of affirmative action, describe the pre-Bakke case law, explain the Bakke decision, and view the concept of diversity as a compelling interest to justify affirmative action. Finally, it will describe some concerns for student affairs administrators that the authors believe will arise in the wake of the Grutter and Gratz decisions, and offer suggestions to solve such dilemmas.

\section{Affirmative Action: Definition and History}

Affirmative action programs have been challenged socially and judicially practically since their inception. Even today, there is clearly disagreement at all levels of government and society about whether affirmative action should be pursued within higher education and employment, despite an emerging societal acceptance of diversity as a fact of life. In a 2002 issue of the Yale Law and Policy Review, Schuck argued that there is a perceived difference between embracing diversity and supporting affirmative action. He noted that while nondiscrimination and accepting diversity are essentially passive, affirmative action implies a systematized, bureaucratized and (most important) continuous way for certain groups to receive preferential treatment. Those types of programs, he argued, do not enjoy the support of most Americans.

A number of types of affirmative action exist, and terminology distinctions may be helpful. Even before Bakke reached the Supreme Court, Goldman (1977) identified four types of affirmative action. In addition to quota systems, which reserve spots for minorities no matter what their qualifications, Goldman described backward, forward, weak reverse discrimination, and strong reverse discrimination affirmative action programs. Simply put, backward programs look to correct past injustice, while forward programs look to ensure future opportunity. 
Weak reverse discrimination gives preferences to minority candidates who are equally qualified to White candidates. Strong reverse discrimination gives preference to minority candidates who are less qualified than White candidates. In affirmative action cases, much of the debate centers on categorizing the program, especially since strong reverse discrimination and quota systems have little public support and are generally held by the courts as disregarding the individual rights guaranteed by the Fourteenth Amendment.

The history of affirmative action can be traced back to the National Labor Relations Act of 1935, which required the National Labor Relations Board to take "affirmative action" against unfair labor practices (Schuck, 2002). Affirmative action in federal employment contracts was an issue in the Kennedy administration, but as Hendrickson (2001) noted, the issue truly came into prominence during the Johnson and Nixon administrations. According to Dixon (1979), Titles VI and VII of the Civil Rights Act of 1964 have been critical to affirmative action cases and represent an attempt to avoid categorizing Americans on the basis of their race, but rather, in the words of Senator Hubert Humphrey, to "treat Americans as Americans." He argued the intent of the legislation was that persons are to be treated equally and fairly based upon their achievements and potential rather than upon their race.

After the passage of Title VI (enforced by the Justice Department's Office of Civil Rights [OCR]) and Title VII (enforced by the Equal Employment Opportunity Commission), President Johnson issued Executive Order 11246, which mandated nondiscrimination in employment by government contractors and subcontractors (Hendrickson, 2001). In 1969, the Nixon administration implemented the "Philadelphia Plan," a backward affirmative action plan, requiring proportional representation of minority contractors as a remedy for past discrimination. After the implementation of the plan, affirmative action policies required numerical baselines that demonstrated past bias and the need for remedy, and a measuring tool to evaluate the effect of the remedy. Thus, early efforts at affirmative action were more focused upon quantitative demonstrations of bias and correcting policies that created potential or actual bias (Schuck, 2002). 
Public attitude towards affirmative action policies grew increasingly skeptical, and in 1995 the California Board of Regents passed a resolution barring the consideration of race in admissions and financial aid aimed at specific racial or ethnic groups in the state's public institutions of higher education (Barry, 2001). A year later, California voters approved Proposition 209, which barred preferential treatment in public employment, education, and contracting — which, according to Barry, effectively ended affirmative action in California. In 1998, voters in the state of Washington voted to eliminate racial considerations in admissions to the state university system, although officials were encouraged to consider an applicant's cultural experiences and disadvantages (Barry).

Meanwhile, the United States Court of Appeals for the Ninth Circuit upheld Justice Powell's finding that diversity is a compelling state interest in Smith v. University of Washington Law School (2000). This indicated a conflict between voters, policy makers in some states, and the federal court system as to the value and legality of affirmative action as social policy. It also demonstrated the difficult position of higher education policy makers.

\section{Case Law Prior to Bakke}

Hendrickson (2001) cited five major cases leading up to Bakke as fundamental for understanding the decision. The first was Plessy v. Ferguson (1896). This case established the concept that "separate but equal" facilities would satisfy the Equal Protection Clause of the Fourteenth Amendment. In response, numerous states created separate institutions of higher education for Blacks. More than 40 years passed before states were forced to create separate professional schools for Blacks as a result of Missouri ex rel Gaines v. Canada (1938). The beginning of the end of separate but equal did not come until 1950 in Sweatt v. Painter. In Sweatt, the Court ruled that the Fourteenth Amendment is violated if the separate programs were not equal. Sweatt provided the judicial toehold for Brown v. Board of Education of Topeka (1954), the decision that ended school segregation as a constitutionally sanctioned process (Hendrickson). 
In the 1960s, the effects of Title VI and Title VII were profound. Legal requirements and enforcement procedures were put in place that required state institutions to conduct business in a new way. While widespread discrimination against women and minorities in higher education was common through the 1960s (Goldman, 1977), colleges and universities began to enroll these students utilizing the types of affirmative action programs described previously. Initially, "favored group status" was given to Blacks, Hispanics, Native Americans, Asians, and women (Schuck, 2002). Later, persons with disabilities and those who came from economically disadvantaged backgrounds were included. Women, in addition to minority students, derived substantial benefits from this new activism. In fact, numerous sources (Cho, n.d.; Jackson, 1999; Kelotra, 2004; Kurtz, 2001) have indicated that women have been the main beneficiaries of affirmative action. The numbers of women in law and medical schools increased exponentially, and smaller but growing numbers of women enrolled in nontraditional (for women) academic programs like astronomy, architecture, and engineering as early affirmative action plans became mainstreamed. The result is that affirmative action as practiced is not simply a Black and White affair.

Though much has been made of affirmative action as a result of 1960s activism, the concept of favoritism in college admissions is as old as colleges themselves. Colleges have traditionally used subjective criteria in selecting the student body, factoring in athletic ability, legacy status, military service, and geographic residence in addition to more objective measures like Grade Point Average or standardized test scores (Schuck, 2002). The issue is far from settled, as President George W. Bush recently made statements opposing legacy admission preferences, despite the likelihood the he himself was the beneficiary of such practices (Fleming, 2004).

However, affirmative action, and in particular quotas and reverse discrimination, proved especially contentious when applied to higher education admissions. Schuck (2002) argued that racial preference programs are in essence "zero-sum" because they not only pit favored against nonfavored groups for a finite number of slots; but also, with the expansion in the numbers of favored groups, preference programs pit favored groups against each other. 
Affirmative action programs designed to increase the numbers of minority students on campus caused much debate within academe (Kaplin \& Lee, 1995). Many believed that qualified nonminority applicants were rejected in favor of less qualified minority ones. In the 1970s, litigation began to appear questioning both the constitutional and statutory legitimacy of affirmative action programs. In particular, were the guarantees of the Fourteenth Amendment of equal protection at odds with the legal requirements of Title VI, and were the practices adopted in response to Title VI in some way at odds with its original intent?

In 1974, the Supreme Court heard DeFunis v. Odegaard, a case that centered on the claim of a White male applicant to the University of Washington Law School. DeFunis alleged that he was denied admission because of affirmative action policies that favored less qualified minorities, asserting that the university discriminated against him on the basis of race, violating his Fourteenth Amendment rights (Kaplin $\&$ Lee, 1995). The Washington State Supreme Court found that the university's affirmative action program served a compelling state interest by (a) creating a racially balanced student body, (b) integrating public higher education, and (c) correcting the shortage of minority attorneys (Kaplin \& Lee). By the time the U.S. Supreme Court reviewed DeFunis, DeFunis was in his last quarter of law school, so the case was dismissed as moot. The Court also vacated the Washington State Supreme Court decision, and one can hear the tensions within the Court that would come to full volume after Bakke. Justice Douglas, in his dissent, noted that while educational policy choices were not normally subject to judicial oversight, in this particular case "the school did not choose one set of criteria [for admission] but two, and then determined which to apply to a given applicant on the basis of his race" (416 US 312, 325). Later, Douglas wrote that the "consideration of race as a measure of an applicant's qualification normally introduces a capricious and irrelevant factor working an invidious discrimination" and that the result would be that "educators and courts are immediately embroiled in competing claims of different racial and ethnic groups that would make difficult, manageable standards consistent with the Equal Protection Clause" (416 US 312, 334). 


\section{Regents of the University of California v. Bakke (1978)}

Allan Bakke, a White male twice rejected by the University of California at Davis Medical School (UCD), claimed he had been discriminated against because of his race. UCD maintained two separate admissions programs; one for "regular" admissions, and a "special" one for members of minority or other disadvantaged groups. In both years Bakke was rejected, applicants with significantly lower scores from the special applicant pool were admitted. Bakke alleged that the dual system violated his Fourteenth Amendment rights, the California Constitution, and Title VI of the Civil Rights Act of 1964. Both the trial court and the California Supreme Court held for Bakke, finding the special admissions program constituted a racial quota system and that, under the strict-scrutiny standard, the "special admissions program was not the least intrusive means of achieving the goals of the admittedly compelling state interests of integrating the medical profession and increasing the number of doctors willing to serve minority patients" (438 US 265, 266). The Board of Regents petitioned the Supreme Court for review, and the Court upheld the California Supreme Court decision that Bakke be admitted to UCD and that the special admissions program was not constitutional. However, race could be taken into account when making admissions decisions, reversing the California ruling.

The case was particularly contentious, and the Court produced six separate opinions with no clear majority decision. In a 1979 California Law Review article, Blasi noted the decision "represents a disturbing failure by the Court to discharge its responsibility to give coherent, practical meaning to our most important constitutional ideals" (p. 21). The lack of consensus resulted in social and legal wrangling that continues today.

Justice Powell announced the Court's decision, with Chief Justice Burger and Justices Rehnquist, Stevens and Stewart concurring in part. Justices Blackmun, Marshall, and White offered dissenting opinions. Justices Brennan, White, Marshall, and Blackmun arrived at different conclusions from Chief Justice Burger and Justices Rehnquist, Stevens, and Stewart, while Justice Powell had his own set of conclusions. Toobin (2005) wrote (on a different case before the Court) that 
it is not always possible to precisely identify the legal issue, "and often the trick for Supreme Court litigators is how to define the question in the most advantageous terms" (p. 36). Clearly, the Court struggled with identifying the controlling issue in Bakke.

\section{Justice Powell's Opinion}

Powell concluded that the special program was unlawful under Title VI and unconstitutional under the Fourteenth Amendment because the plan was focused solely on race (Blasi, 1979 [emphasis added]). Powell wrote:

(r)acial and ethnic classifications of any sort are inherently suspect and call for the most exacting judicial scrutiny. While the goal of achieving a diverse student body is sufficiently compelling to justify special consideration of race in admissions decisions under some circumstances, petitioner's special admissions program, which forecloses consideration to persons like respondent, is unnecessary to the achievement of this compelling goal and therefore invalid under the Equal Protection Clause. (438 US 265, 267)

Under Powell's ruling, institutions could seek to achieve diversity through affirmative action programs, but were not compelled to do so; therefore, certain types of institutions (e.g., Historically Black Colleges and Universities [HBCUs]) could remain homogeneous if they had a reasonable basis to do so (Dixon, 1979). However, strict scrutiny would apply to any such program because of the potential for abuse in any race-specific program (Grosset, 2001).

Addressing the constitutional issue, Powell noted a long period of "dormancy" for the Equal Protection Clause, and that by the 1930s it was "no longer possible to peg the guarantees of the Fourteenth Amendment to ... one racial minority" and that the United States is a "(n)ation of minorities ... not a monolithic majority, but a "majority' composed of various minority groups of whom it was said-perhaps unfairly in many cases - that a shared characteristic was a willingness to disadvantage other groups" (438 US 265, 292). The interpretation of the Equal Protection Clause, Powell wrote, was done with the view to "assure all persons 'the protection of equal laws"' (438 US 
265 , 294). Finally, Powell felt there would be no principled way to decide which groups should receive preferential status (Dixon, 1979). Echoing Justice Douglas in DeFunis, Powell wrote:

(n)othing in the Constitution supports the notion that individuals may be asked to suffer otherwise impermissible burdens in order to enhance the societal standing of their ethnic groups. Secondly, preferential programs may only reinforce common stereotypes holding that certain groups are unable to achieve success without special protection based on a factor having no relationship to individual worth. (438 US 265, 298)

Responding to the Board of Regents' claims that the special program was permissible, Powell rejected their assertions that the program would (a) reduce the lack of minorities in medical schools, (b) counter the effects of societal discrimination, and (c) increase the number of doctors serving minority communities. However, Powell did find merit in the argument that the program would provide educational benefits flowing from an ethnically diverse student body, stating that it was a "constitutionally permissible goal for an institution of higher education" (438 US 265, 312). Interestingly, Powell chose to frame this portion of his opinion within the context of academic freedom, which he noted is "not a specifically enumerated constitutional right [but] long has been viewed as a special concern of the First Amendment" (438 US 265, 312).

\section{Concurring and Dissenting Opinions}

Justice Stevens, joined by Chief Justice Burger and Justices Rehnquist and Stewart, concurred with Powell's decision but concluded that the statutory principle was at issue in the case, and that Bakke was excluded from UCD in violation of Title VI (438 US 265, 267). Stevens felt that Title VI embodied a color-blind standard for admissions (Blasi, 1979) and that the case failed to reach constitutional status. As a case with simply two litigants, it was "perfectly clear that the question whether race can ever be used as a factor in admissions decisions is not an issue in this case, and that discussion of that issue is inappropriate" (438 US 265, 411). Even though both parties asked the Court to resolve the constitutional issue, Stevens wrote that the Court's "settled practice, however, is to avoid the decision of a constitutional issue if a case can be fairly decided on statutory ground" (438 US 265, 411). 
The UCD program allowed Whites to compete for 84 admission slots, while minority applicants could apply for all 100 admission slots. Stevens felt that this put the nonminority applicants at a disadvantage, especially given that the two-track system admitted Blacks who scored in the $30^{\text {th }}$ percentile while denying admission to Whites who scored in the $90^{\text {th }}$ percentile (Dixon, 1979). The "plain language" of Title VI, Section 601 meant that excluding Bakke from UCD because of his race could not be justified "unless that language misstates the actual intent of Congress" (438 US 265, 413). Although their reasoning was different from Powell's, this combination of five votes meant that Bakke was "entitled to an order that he be admitted to the University" (438 US $265,325)$.

Justices Brennan, Blackmun, Marshall, and White (hereafter, the Brennan Group), concurring in part and dissenting in part, felt that race may be a factor as long as it corrects "disadvantages cast on minorities by past racial prejudice, at least when appropriate findings have been made by judicial, legislative, or administrative bodies with competence to act in this area" (438 US 265, 325). The justices felt that a special admissions program like UCD's was not invalid simply because it set aside a certain number of slots for qualified minority applicants. Once again, although the reasoning was different from Powell's, the five Justices combined to hold that race may be a factor and that diversity is a compelling interest.

Raising the constitutional issue, the group noted that the Equal Protection Clause was "largely moribund so that, as late as 1927, Mr. Justice Holmes could sum up the importance of that Clause by remarking that it was the "last resort of constitutional arguments"' (438 US 265, 326). Worse, the clause was actually turned against those whom it was supposed to protect, resulting in the "separate but equal" doctrine, a status that was "always separate but seldom equal" (438 US $265,327)$. Color-blind law, was, in this opinion, a fantasy. In ringing language, the group asserted that neither Title VI nor the Constitution required it and that color-blindness could "become myopia which masks the reality that many 'created equal' have been treated within our lifetimes as inferior by both the law and their fellow citizens" (438 US 265, 327). Protections guaranteed by Title VI rose to constitutional status because that was the intent of the legislators who created it; indeed, they believed Congress equated Title VI with the commands 
of the Fourteenth Amendment and that "any claim that the use of racial criteria is barred by the plain language of the statute must fail in light of the remedial purpose of Title VI and its legislative history" (438 US 265, 340).

Justice White focused his dissent on the legal issue of whether a private cause of action existed under Title VI. Noting Justice Stevens' opinion that it was inappropriate to discuss the constitutional issue if the case could be decided on a statutory basis, Justice White was unwilling to assume the Court had jurisdiction to decide the Title VI claim. However, because other justices assumed that the statutory issue should be decided upon, White acknowledged that the issue must be addressed (438 US 265, 387).

Justice Blackmun made a critical observation that a "time will come when an 'affirmative action' program is unnecessary and is, in truth, only a relic of the past" (438 US 265, 403). Blackmun hoped that this would happen within the next decade, but until then affirmative action programs could never be race-neutral. He wrote:

To ask that this be so is to demand the impossible. In order to get beyond racism, we must first take account of race. There is no other way. And in order to treat some persons equally, we must treat them differently. We cannot-we dare not-let the Equal Protection Clause perpetuate racial supremacy. ( 438 US 265, 407)

Finally, Justice Marshall found that the consideration of race in admissions decisions was permissible and that the UCD program did not violate the Constitution. Marshall's distress was palpable:

(i)t must be remembered that, during most of the past 200 years, the Constitution as interpreted by the Court did not prohibit the most ingenious and pervasive forms of discrimination against the Negro. Now, when a state acts to remedy the effects of that legacy of discrimination, I cannot believe that this same Constitution stands as a barrier. (438 US 265, 387)

And:

while I applaud the judgment of the Court that a university may consider race in its admissions process, it is more than a little 
ironic that, after several hundred years of class-based discrimination against Negroes, the Court is unwilling to hold that a class-based remedy for that discrimination is permissible. (438 US 265, 400)

The historical fact of discrimination meant that "we now must permit the institutions of this society to give consideration to race in making decisions about who will hold the positions of influence, affluence and prestige in America" (438 US 265, 401).

\section{The Results of Bakke}

Bakke established that diversity is a compelling state interest, yet it did not specify how race could be considered in an admissions program and survive strict scrutiny (Grosset, 2001). Both courts and schools were left to determine for themselves how to achieve diversity without violating Title VI or the Fourteenth Amendment.

Adding to the confusion was the divided Court's elevation of the statutory (Title VI) issue to a constitutional level, finding that Congress intended to incorporate the protections of the Fourteenth Amendment into Title VI (Kaplin \& Lee, 1995). However, because the UCD special admissions program was clearly based on race alone, it did not survive strict scrutiny as the "least burdensome alternative" to remedy discrimination.

In a California Law Review article in 1979, Greenawalt stated that Bakke forced a choice between two liberal ideals. The first is that groups that have been subject to discrimination should be afforded equal opportunity. The second is that "justice precludes assigning benefits and burdens on the arbitrary basis of racial and ethnic terms" (p. 87). Thus, when members of minority groups received benefits at the expense of Whites who had superior academic records, philosophical tension ensued; and this is reflected in the multiple opinions of the Court (Greenawalt). Lacking a definitive ruling from the Court, Bakke inspired additional litigation as the social definition of affirmative action evolved. 


\section{Case Law Since Bakke}

Several cases since Bakke have attempted to clarify the issue of affirmative action, both in employment and education, but the fact remains that because no clear majority of the justices subscribed to any whole opinion, the record remains cloudy. There is something for everyone in the six opinions, so even as the Court has welcomed new Justices with different philosophies, no one opinion came to be seen as decisive. Powells' opinion, which came to be seen as controlling in Bakke, was relatively narrow in that it permitted race to be a factor in admissions as long it wasn't the only factor. The opinion was politically attractive because it neither demanded large-scale affirmative action programs with fixed numbers of ethnic proportionality, nor required strictly color-blind admissions (Dixon, 1979 [emphasis added]). However, cases still arose that challenged affirmative action policies and the courts were forced to rule.

In Wygant v. Jackson Board of Education (1986), the Court held that there must be a connection between past discrimination and the remedy (Hendrickson, 2001). As time passed, the appointment of more conservative Justices meant that a plurality of the Court no longer believed that government redress for past racial injustice was a compelling reason for sustaining affirmative action programs (Lewis, Lewis, \& Ponterotto, 1990). In City of Richmond v. J.A. Crosson Co. (1989), the Court held that simply asserting an interest in remedying societal discrimination did not survive strict scrutiny (Grossett, 2001). In essence, any legislative attempt to correct past discrimination based on race must withstand strict scrutiny (Lewis et al., 1990 [emphasis added]). While affirmative action programs are permissible under the Fourteenth Amendment, any program must be "narrowly tailored to remedy identified discrimination" (p. 35).

Just 1 year later, however, the Court heard Metro Broadcasting v. FCC (1990), and held that the government did have a substantial interest in promoting diversity in the issuance of broadcast licenses (Grossett, 2001). The Metro decision was overruled in Adarand v. Peña (1995), although the Court did not disavow the concept of diversity as a compelling interest (Grossett). 


\section{The Effect of Bakke on Higher Education Case Law}

The Circuit Courts have had a difficult time interpreting not only the variety of opinions contained within the Bakke decision, but also the conflicting messages the Court has sent in subsequent affirmative action cases. No majority of Supreme Court justices has ever voted to deny diversity as a compelling state interest; but prior to Gratz and Grutter, commentary from some justices displayed increasing hesitation in this area (Grossett, 2001). The large number citations of Bakke in the various levels of the court system demonstrated the belief that Bakke was indeed controlling (Grossett), but much argument has been centered on which of the six opinions is truly represents the correct reading of the law.

Clearly, different courts have reached different conclusions. In Smith v. University of Washington Law School (2000), Justice Powell's opinion was controlling. The U.S. Court of Appeals for the Ninth Circuit held that under Marks v. United States (1977), when a divided court produces a decision to which no majority subscribes in its entirety, the holding is the position taken by the justices who concurred on the narrowest grounds (Grossett, 2001). Even though Justice Stevens' opinion had enough votes to void the UCD program, a majority of justices allowed some race-based considerations in educational admissions under Title VI. Therefore, Powell's opinion, which is narrower than either Stevens' or the Brennan Group's, was controlling (Grossett). Accordingly, diversity is a compelling interest that survives strict scrutiny (Coyle, 2001).

The Smith ruling stands in opposition to Hopwood v. Texas (1996). In Hopwood, the state maintained that a dual admissions program was necessary to meet OCR requirements to bring Texas within Title VI guidelines. The District Court found that the state had failed to demonstrate a compelling interest but had provided legitimate reasons for nondiscriminatory denial of admission (Hendrickson, 2001). The U.S. Court of Appeals for the Fifth Circuit disagreed, reversing the decision and finding that the dual admissions programs violated the Equal Protection Clause (Hendrickson) and that Justice Powell's opinion that diversity is a compelling state interest was not binding 
(Grossett, 2001). The Fifth Circuit Court ruled that since no other justice had ever joined Powell's section on diversity, the opinion was not controlling (Grossett). The Supreme Court declined to hear the case after the state of Texas altered the admissions process, rendering the case moot (Hendrickson). The Hopwood rationale was then used by the District Court in another affirmative action case, Johnson v. Board of Regents of the University of Georgia (2000). Obviously, the lower courts were coming to different conclusions, and the higher education establishment was looking for guidance. The issue simmered until Gratz and Grutter.

\section{Diversity as a Compelling Interest}

In the Bakke decision, the Brennan Group felt that Title VI incorporated the Equal Protection Clause and that race-conscious admissions programs to correct past discrimination were permissible even if they applied quotas (Greenawalt, 1979). Their opinion stated:

Such relief does not require as a predicate proof that recipients of preferential advancement have been individually discriminated against; it is enough that each recipient is within a general class of persons likely to have been the victims of discrimination. Nor is it an objection to such relief that preference for minorities will upset the settled expectations of nonminorities. (438 US 265, 363)

Powell agreed to elevating Title VI to include Fourteenth Amendment protections but felt that achieving diversity in higher education was the preferable criteria for race-based admission (Greenawalt). There was no evidence of prior discrimination requiring remediation at $\mathrm{UCD}$, and slots were reserved for minorities solely on the basis of race; therefore, the program was unconstitutional (Hendrickson). The legacy of Powell's decision, then, is that the Constitution does not necessarily require color-blind admissions. They are permissible if the state demonstrates a compelling interest and if there is no other nonracial way of correcting the discrimination (Henkin, 1979). States may use specific instances of discrimination as a compelling interest, even if the remedy comes at the expense of other individuals, as the Brennan Group noted; but attempting to correct the legacy of social discrimination against minorities by assigning quotas will not withstand strict scrutiny (Henkin). 
The attempt to correct past discrimination against groups is referred to as the restitution principle. In its narrowest sense, restitution is an attempt by the government to assist Blacks who are the descendants of slaves and suffered racial discrimination through the 1960s (Schuck, 2002). Because the government either stood passively by when the discrimination occurred, or was actively involved, Schuck noted that restitution is simply a method of righting a past wrong. However, once the restitution argument took hold, other groups alleging discrimination made similar claims. Women, Native American, Chinese, Japanese, Jewish, and Hispanic people had all suffered discrimination in which the government played either an active or passive role. Extension of preferential status to members of these groups, Schuck argued, did little to promote equality, but rather established a competition for resources.

Diversity as a compelling interest became increasingly important in affirmative action cases as other rationales failed to survive judicial review. Racial balancing through quotas was impermissible after Bakke, the "positive role model" theory was discredited in Wygant, legislatures could not make broad categories for remedy after Crosson, and affirmative action could not be considered permanent or a justification for proportional representation after Lutheran Church Missouri Synod v. FCC (1998) (Pavela, 2002).

Today, Schuck (2002) argues, diversity as a compelling interest is not about correcting past discrimination, but is rather "a rhetorical Hail Mary pass ... made in desperation when all other arguments for preferences have failed" (p. 16). According to Van Tassell (2001), the diversity rationale suggests that the government must ensure that institutions of higher education have enough underrepresented minorities on campus, even if it means pushing other groups aside.

While many admissions and student affairs professionals might disagree, there does appear to be a growing body of comment that agrees with Schuck's and Van Tassell's analyses. As public opinion has swung against affirmative action (e.g., the California and Washington ballot initiatives), institutions have more consistently argued for the diversity rationale. This makes sense since most colleges have rarely engaged in the kinds of discrimination that would allow race-based admissions to survive strict scrutiny (Schuck, 2002). 
A study by Bowen \& Bok (2000), who support affirmative action, revealed significant SAT score differentials between Black and White applicants. As top colleges struggle to admit enough qualified minority students to achieve diversity, they are forced to offer slots to less qualified minority students. Schuck (2002) argued that as one moves "down the food chain" into second- and third-tier colleges, the demand for diversity forces those colleges to admit students they know will have academic difficulty.

Another issue with the diversity rationale is that it implies all members of a particular ethic group think and act alike (Pavela, 2002). Pavela argued that the diversity rationale has done little other than provoke additional litigation while failing to provide a truly compelling interest. Since Hopwood, diversity as a compelling interest has been under attack; and according to White (2001), "even judges who are willing to acknowledge its continued vitality do so grudgingly" (p. 10).

\section{Gratz and Grutter: Admissions at UM}

Two cases involving UM were heard during the 2002-2003 Supreme Court term and have provided updated, if not fully clear, guidance needed by institutions throughout the United States. In these cases, the Court sought to clarify the major issues and provide a more conclusive interpretation on affirmative action in college admissions.

The first case, Gratz v. Bollinger (2003), concerned White applicants to UM who were wait-listed but not admitted to the undergraduate College of Literature, Science and the Arts (LSA) in 1995 and 1997. The admissions program gave special consideration to individuals based on race, but it did not extend those considerations to Whites. In 2000, the District Court held that the LSA had a compelling interest in considering race, but that from 1995-1998 the LSA program was essentially a quota system, and therefore not valid (Barry, 2001; Coyle, 2001; Hendrickson, 2001). While Gratz was on appeal at the United States Court of Appeals for the Sixth Circuit, the same court issued its ruling in the other UM case, Grutter. The Supreme Court decided to hear both cases at the same time, even though the Sixth Circuit had not yet ruled on Gratz. 
The second case, Grutter v. Bollinger (2003), is more complex. The case involved admissions procedures at the UM Law School. Upon being denied admittance to the Law School, Grutter filed suit saying the Law School used race as a predominant factor in its decision. At trial, the admissions process was detailed. A scoring grid was used to plot applicants - the further to the top right of the grid one was placed, the greater chance one had for admission. The process also considered whether or not a student would help the Law School achieve diversity. The plaintiffs maintained that minorities had a greater statistical chance of admission than Whites. The District Court found the plan unlawful, while the Sixth Circuit reversed that finding. The Circuit Court held that achieving diversity was a compelling interest and that the policy to admit a "critical mass" of minority students did not violate either Title VI or the Fourteenth Amendment (Ogletree, 2002).

The expedited review of Gratz allowed the Court to review both UM cases and provide guidance on an issue where the District Court had arrived at opposite decisions regarding admissions procedures within the same institution. According to Wilgoren (2002), the Supreme Court very rarely agrees to hear cases prior to the lower court ruling; perhaps significantly, Brown was one of those rare cases. The combination of the inability of the District and Appeals courts to rule consistently, the demand by institutions of higher education for clarification, the willingness of lower courts to overlook Justice Powell's opinion, and the increasingly conservative nature of the Supreme Court led many to believe that Gratz and Grutter would spell the end for Bakke. As it turned out, this was not the case.

Amidst a flurry of publicity, including a remarkable public division within the Bush administration, with its two most prominent AfricanAmerican leaders openly disagreeing with the official administration position, and an unprecedented number of amicus curiae briefs (a nonparty that volunteers or is invited by the court to submit its views on the issues because it has an interest or perspective on the matter that may not be adequately represented [Clapp, 2000]), the Court heard oral arguments in both cases. The Court, applying strict scrutiny, recognized that the creation of a diverse educational environment was a compelling state interest and that UM was within its rights to pursue such a student body. 
Chief Justice Rehnquist wrote the opinion for Gratz. The Court held that the LSA's admissions policy was not narrowly tailored because it automatically awarded 20 points (out of a possible 100) "to every "underrepresented minority' applicant solely because of race" (539 US $244,270)$. Because the LSA policy did not consider individuals, it was contrary to Justice Powell's opinion in Bakke and therefore improper. Justice O'Connor, in her concurrence, wrote "even the most outstanding national high school leader could never receive more than five points for his or her accomplishments, merely a quarter of what a minority applicant received based solely on race" (539 US 244, 279). In addition, the Chief Justice rejected UM's claim that the volume of admissions applications made it impractical to provide the individual attention that the Court required: "the fact that the implementation of a program capable of providing individualized consideration might present administrative challenges does not render constitutional an otherwise problematic system" (539 US 244, 275).

While the 6-3 ruling was clear enough, the case was still contentious and the Court produced seven opinions, including dissents from Justices Stevens, Souter, and Ginsburg. While Stevens and Souter denied that Gratz had standing to bring the action, Ginsburg echoed Justice Marshall's call for social action in Bakke. "The racial and ethnic groups to which the College accords special consideration . . . historically have been relegated to inferior status by law and social practice; their members continue to experience class-based discrimination to this day" (539 US 244, 303).

She continued:

The stain of generations of racial oppression is still visible in our society . . . and the determination to hasten its removal remains vital. . . . If honesty is the best policy, surely Michigan's accurately described, fully disclosed College affirmative action program is preferable to achieving similar numbers through winks, nods, and disguises. (539 US 244, 304)

The Grutter majority, however, held that the affirmative action program at the UM Law School was narrowly tailored and thus an acceptable means to achieve educational diversity. The Court specifically endorsed Justice Powell's view that diversity is a compelling interest 
and that educational institutions have the authority to decide that diversity is essential to their missions. Once again, the fractious nature of affirmative action played out in the Court ruling. Justice O'Connor wrote for the 5-4 majority, with Justices Thomas and Scalia concurring in part and dissenting in part, while Chief Justice Rehnquist and Justice Kennedy filed dissenting opinions.

Justice O'Connor held that the "hallmark of [the Law School's] policy is its focus on academic ability coupled with a flexible assessment of applicants' talents, experiences, and potential to 'contribute to the learning of those around them"' (539 US 306, 315). Because diversity is not defined solely on the basis of race or ethnicity, the Court held that the policy sought to guide admissions officers in producing diverse and academically outstanding classes.

The opinion acknowledges both the weight of the expertise from all the amicus briefs, and the need for resolution, specifically citing the Appeals Court opposite decisions in Smith (diversity is a compelling interest) and Hopwood (it isn't). In his Gratz opinion, Chief Justice Rehnquist noted that while no Supreme Court case since Bakke had specifically affirmed diversity as a compelling interest, neither had it ruled it out (539 US 244, 258). In Grutter, however, Justice O'Connor wrote "today we endorse Justice Powell's view that student body diversity is a compelling state interest that can justify the use of race in university admissions" (539 US 306, 326).

She expanded:

Context matters when reviewing race-based governmental action under the Equal Protection Clause. . . . Not every decision influenced by race is equally objectionable and strict scrutiny is designed to provide a framework for carefully examining the importance and sincerity of the reasons advanced by the governmental decisonmaker for the use of race in that particular context. (539 US 306, 327)

While finding that the Law School admissions program withstood strict scrutiny, and unambiguously stating that diversity is a compelling interest, Justice O'Connor made it clear that such policies would not be acceptable forever. Echoing Justice Blackmun in Bakke, 
Justice O'Connor stated that the true purpose of the Fourteenth Amendment was to eliminate all governmentally imposed discrimination based on race and that:

Race-conscious admission policies must be limited in time. . . . Enshrining a permanent justification for racial preferences would offend this fundamental equal protection principle. We see no reason to exempt race-conscious admissions programs from the requirement that all governmental use of race must have a logical end point.(539 US 306, 342)

Justice O'Connor concluded that " 25 years from now, the use of racial preferences will no longer be necessary to further the interest approved today" (539 US 306, 343).

\section{The Aftermath of Gratz and Grutter}

The two rulings seemed to provide proponents of affirmative action a major victory. The Court held that affirmative action when used in a narrowly tailored manner was permissible. It upheld Justice Powell's opinion that achieving diversity through affirmative action was a compelling state interest. It provided two examples of the strict scrutiny that the Court would use to review admissions policies, and it demonstrated that the Fourteenth Amendment protects individual rights, rather than providing special protections to favored groups.

Naturally, there was great public interest in the rulings, and like the Court opinions, the reviews were mixed. Linda Chavez, president of the Center for Equal Opportunity, was quoted in the July 4, 2003 Chronicle of Higher Education saying that "Grutter and Gratz do not settle the affirmative action debate, but lay the groundwork for more lawsuits, more divisiveness, and more racial stereotyping" (p. B10). The same article had M. Lee Pelton, president of Willamette College, opining "The Court said 'no' to those who seek to undo decades of hardearned social progress-who want the nation to turn its back on its commitment to equality and social justice" (pp. B10-B11).

In a 2003 online law and legislation journal article, Julian suggested:

While this decision answered many important questions, it also left unanswered quite a few others. Furthermore, Justice Scalia, an 
adamant and strident opponent of affirmative action, in effect drew a roadmap for those who wished to attack the decision in the federal courts in the future. His words alone are almost sure to draw the attention and resources of various conservative organizations that have vowed to continue to fight against racial preferences of any kind.

Julian (2003) also suggested that there are still many points of vulnerability to which opponents of affirmative action might take this fight. He reported the distinct possibility of an attempt to amend the Constitution to prohibit racial preferences, the increasing number of conservative federal judges, the susceptibility to challenge of special scholarship programs, the need for institutions to closely monitor their programs to assure individual consideration of applicants, the necessity for a time frame for ending affirmative action programs, and a definition of what a "critical mass" of underrepresented minorities is at a particular institution.

The February 25, 2005 issue of the Chronicle of Higher Education carried a special section on "Admissions and Student Aid." Jonathan Alger, a legal coordinator of the UM cases, and now a legal counsel to Rutgers University, indicated several areas of concern with putting the Gratz and Grutter rulings into practice. He noted that institutions must carefully define what they mean by "diversity," ensure that "merit" was still the primary deciding factor in admissions, assess financial aid programs to ensure equitable benefits, and seek race-neutral programs whenever possible. He suggested that in Gratz and Grutter, the Court "acknowledged that race still matters in our nation, and that much remains to be done to ensure true equality of opportunity throughout all of our institutions" (p. B28).

\section{Conclusion}

The literature is clear: Admissions staffs, student affairs professionals, and university legal departments must remain vigilant whenever addressing admissions and other campus policies that provide special consideration for minorities and other underrepresented groups. The Supreme Court, while affirming diversity as a compelling interest, clearly indicates that such support cannot last forever, suggesting that 
race-neutral admissions processes need to be developed. Certainly a more holistic approach to admissions-one which emphasizes an applicant's references, test scores, and written work along with individual interviews-is what the Court has requested. Programs can be developed at the secondary and postsecondary levels that assist in attracting minority applicants without resorting to proscribed techniques.

The history of affirmative action is long and fraught with twists and turns. The Court has now provided what many believe to be a temporary reprieve in the fight to end affirmative action, but, as Justice O'Connor noted, within the next generation affirmative action programs should cease to be necessary. There are clearly some on the current Court who would have that end come more rapidly. A reconfigured Court may be able to reach such a result with two new (presumably conservative) members nominated by President Bush joining the Court in its next term.

The Court has often proved ineffective in providing remedies for seemingly intractable social problems like slavery in the $19^{\text {th }}$ century and reproductive rights in the $20^{\text {th }}$ century. Affirming Justice Powell's opinion but putting it on a timetable is a signal that the Court would like to move away from this issue altogether. But no matter how much "strict constructionists" and "original intent" advocates want a more limited Court, it seems that the litigious nature of American society, combined with permanent, partisan culture wars, means that the Court will continue to be called on to clarify and resolve issues that defy easy legislative answers.

The Court indicated in Grutter that it is up to institutions of higher education to determine how to deal with issues of diversity on campus, and that those institutions need to determine for themselves what a "critical mass" of minority students is, without resorting to race-conscious programs. For now, institutions must closely look to Gratz and Grutter in developing programs that promote diversity on campus, knowing full well that even if the programs are successful they may be opening themselves to legal action, and that even legal programs must be phased out in the near future. 
Those who have developed and provided race-based scholarships have recognized this fact. Schmidt (2004a) noted that "(c)olleges throughout the nation are quietly opening a wide variety of minority programs to students of any race, mainly to avoid being accused of discrimination" ( $\mathbf{9} 3$ ). He also wrote that nonprofits and federal agencies that make such scholarships are considering doing the same. While there is concern that this change will reduce the number of minorities who receive these scholarships, Theodore Shaw of the National Association for the Advancement of Colored People's Legal Defense and Educational Fund suggests that "the jury is going to be out until we find out if there is any significant change in the number of minority students who are being reached" (quoted in Schmidt, 9 9).

Schmidt (2004b), notes that the president of the Andrew Mellon Foundation, William Bowen, recommended that selective colleges give preference in admission to economically disadvantaged students, which would have the effect of increasing the chances for all lowincome students, whether or not they belong to one of the traditional minority groups.

The College Board has developed three manuals to help colleges determine whether their financial aid programs pass muster under the rulings of the Court. In an interview with the Chronicle of Higher Education, the author of the volume on diversity programs, Arthur L. Coleman, focused on the need for individual institutions to develop their own programs, and that the manual is designed to provide a baseline for decision making and a guide for working through the process (Selingo, 2005).

Practically speaking, admissions and financial aid professionals will need to take the lead in the new efforts at achieving diversity on campus. However, senior administrators will have to set policies that allow them to do so, and academic affairs professionals and faculty will need to seek ways to help all students succeed. Student affairs professionals will continue to be responsible for creating a campus environment that attracts and retains students who add to the diversity on campus.

Institutions may provide legal admissions interventions and support. This may be particularly true for high-prestige universities where competition for admission is intense, but it holds true for most col- 
leges and universities who have, as the Court has made clear, a compelling interest in a diverse student body that contributes to a robust educational environment. Recall that the UM Law School accepts only $10 \%$ of its applicants; yet, it was able to design a program that allowed for a diverse student body, and administrative difficulty in processing large numbers of applications is not a defense for a lack of a flexible, individualized program.

Institutions may attract more minority applicants and find them capable of success if they do the following:

- create academic support programs in high schools, and by so doing support efforts to better prepare minority and economically disadvantaged students for admission;

- recruit from community colleges that have large minority populations;

- $\quad$ lace reduced emphasis on standardized test scores and increased emphasis on personal interviews to assess potential for success; and

- increase consideration of economic factors in awarding financial aid.

Student affairs administrators must also provide support for all students with limited academic abilities or those who do not have familial or peer support systems. This can be achieved by:

- providing learning assistance programs, including tutoring, for underrepresented groups, including minorities and first-generation college students;

- providing proactive and appropriate academic advising from admission through graduation, perhaps modeling it on successful programs pioneered by HBCUs;

- providing learning communities that stress academic support and cohort development across all races;

- forming coalitions with other local institutions so students who do not yet form a "critical mass" at one institution can have external support; 
- providing outreach and support to those taking developmental courses; and

- working closely with community colleges to develop academic support for likely transfer students.

Finally, it is critical that student affairs professionals look long term, that they work cooperatively with high schools and community colleges, and that they seek creative solutions for the challenges of those who have not traditionally made up the bulk of American college students. Affirmative action has not fully solved issues of access in higher education; and a new Supreme Court Justice could easily swing the Grutter decision the other way, ending state-sanctioned affirmative action in higher education and moving Justice O'Connor's time line ahead significantly. Student affairs professionals must search for ways to create real diversity on campus and support all students.

\section{References}

Adarand v. Peña, 515 US 200 (1995).

Alger, J. (2005, February 25). Putting the Michigan ruling into practice. Chronicle of Higher Education, p. B28.

Barry, E. (2001, October). Affirmative action. Presented at the general session of the Eleventh Annual Conference on Legal Issues in Higher Education. University of Vermont.

Blasi, V. (1979, January). Bakke as precedent: Does Mr. Justice Powell have a theory? California Law Review, 67 (1). Retrieved September 25, 2002 from http://lexis-nexis.com

Bowen, W. G., \& Bok, D. (2000). The shape of the river: long-term consequences of considering race in college and university admissions. Princeton, NJ: Princeton University Press.

Brown v. Board of Education of Topeka, 347 US 483 (1954).

Cho, S. (n.d.). Race, racism and the law. White women and affirmative action. Excerpted from Cho, S. (2002, Winter). Ambivalence towards affirmative action: Theorizing political accountability in coalitions. University of Missouri Kansas City Law Review, 71, 399-402. Retrieved January 17, 2005 from http://academic.udayton.edu/race/ 04needs/affirm23.htm

City of Richmond v. J.A. Crosson Co., 488 US 469 (1989). 
Clapp, J. (Ed.). (2000). Random House Webster's dictionary of the law (1 ${ }^{\text {St }}$ ed.). New York: Random House.

Coyle, M. (2001, January 25). It's Baa-aa-ke! National Law Journal. Retrieved September 25, 2002 from http://www.lexis-nexis.com

DeFunis v. Odegaard, 416 US 312 (1974).

Dixon, R. (1979, January). Bakke: A constitutional analysis. California Law Review, 67 (1). Retrieved September 25, 2002 from http://lexis-nexis.com

Fleming, B. (2004, August 9). Bush says colleges' admissions offers should be based on merit, not legacy preferences. Chronicle of Higher Education. Retrieved August 11, 2004 from http://chronicle.com/prm/daily/2004/08/2004080901n.htm

Goldman, A. (1977). Affirmative action. In M. Cohen, T. Nagel, \& T. Scanlon (Eds.), Equality and preferential treatment. Princeton, NJ: Princeton University Press.

Gratz et al. v. Bollinger et al., 539 US 244 (2003).

Greenawalt, K. (1979, January). The unresolved problem of reverse discrimination. California Law Review, 67 (1). Retrieved September 25, 2002 from http://www.lexis-nexis.com

Grossett, J. (2001, Fall). Upholding racial diversity in the classroom as a compelling interest. Case Western Law Review, 52 (1). Retrieved September 25, 2002 from http://www.lexisnexis.com.helin.uri.edu

Grutter v. Bollinger et al., 539 US 306 (2003).

Hendrickson, R. (2001). Rethinking affirmative action: Redefining compelling state interest and merit in admission. Peabody Journal of Education, 76 (1). Retrieved September 25, 2002 from http://web15.epnet.com

Henkin, L. (1979, January). What of the right to practice a profession? California Law Review, 67 (1). Retrieved September 25, 2002 from http://www.lexis-nexis.com

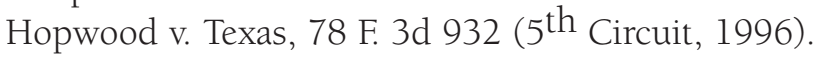

In reactions to the Michigan rulings, diversity abounds. (2003, July 4). Chronicle of Higher Education, pp. B10-B12.

Jackson, J. (1999, January/February). Extra! Affirmative action coverage ignores women and discrimination. Retrieved January 17, 2005 from http:fair.org/extra/9901/affirmative-action.html

Johnson v. Board of Regents of the University of Georgia, 106 F. Supp. 2d 1362 (2000). 
Julian, F. H. (2003, Summer). NASPA Region III Law and Legislation Quarterly. Washington, DC: National Association of Student Personnel Administrators. Retrieved September 4, 2003 from http://www.murraystate.edu/qacd/cbpa/polcrjlst/quarterly/summer2003.html (Document removed from online source. Original available from author).

Kaplin, W., \& Lee, B. (1995). The law of higher education (3 ${ }^{\text {rd }}$ ed.). San Francisco: Jossey-Bass.

Kelotra, R. (2004, September 3). Civilrights.org. Women's groups plan affirmative action campaign in Michigan. Retrieved January 17, 2005 from http://www.civilrights.org/issues/affirmative/details. cfm?id24996

Kurtz, S. (2001, September 10). National Review Online. Breaking the silence. Retrieved January 17, 2005 from http://www. nationalreview.com.contributors/kurtz091001.shtml

Lewis, D., Lewis, L., \& Ponterotto, J. (1990). Legal aspects of affirmative action. In J. Ponterotto, D. Lewis, \& R. Bullington (Eds.), New directions for student services: Affirmative action on campus. San Francisco: Jossey-Bass.

Lutheran Church Missouri Synod v. Federal Communications Commission, 141 F. 3d 344 (DC Circuit, 1998).

Marks v. United States, 430 US 188 (1977).

Metro Broadcasting v. Federal Communications Commission, 497 US 547 (1990).

Missouri ex rel Gaines v. Canada, 305 US 337 (1938).

Ogletree Jr., C. (2002, May 19). The future of admissions and race. The Boston Globe, p. E7. Retrieved September 25, 2002 from http://www.lexis-nexis.com

Pavela, G. (Ed.). (2002, September 4). Putting "diversity theory" to the test. Synfax Weekly Report: Commentary on critical issues in higher education.

Plessy v. Ferguson, 163 US 537 (1896).

Regents of the University of California v. Bakke, 438 US 265 (1978).

Schmidt, P. (2004a, March 9). Not just for minority students anymore. Chronicle of Higher Education. Retrieved March 31, 2005 from http://chronicle.com/weekly/v50/i28/28a02601.htm

Schmidt, P. (2004b, April 16). Noted higher education researcher urges admissions preferences for the poor. Chronicle of Higher 
Education. Retrieved March 31, 2005 from http://www.chronicle. come/weekly/v50/i32/32a02601.htm

Schuck, P. (2002). Affirmative action: Past, present and future. Yale Law and Policy Review, 20 (1). Retrieved September 26, 2002 from http://www.lexis-nexis.com

Selingo, J. (2005, March 28). New guidebook will help race based student aid programs avoid straying from Supreme Court rulings. Chronicle of Higher Education. Retrieved March 31, 2005 from http://www.chronicle.com/prm/daily/2005/03/2005032804n.htm

Smith v. University of Washington Law School, 233 F 3d 1188 (9th Circuit, 2000).

Sweatt v. Painter, 339 US 629 (1950).

Toobin, J. (2005, August 1). Annals of law: Sex and the supremes. The New Yorker, pp. 32-37.

Van Tassell, M. (2001/2002, December/January). Under the skin of diversity. The Abolitionist Examiner. Retrieved January 17, 2005 from http://www.multiracial.com/abolitionist/word/vantassell5.html

White, L. (2001, October). The pursuit of diversity: The legal landscape of affirmative action and evolving strategies. Presented at the Eleventh Annual Conference on Legal Issues in Higher Education, University of Vermont.

Wilgoren, J. (2002, October 1). Justices asked to rule early on university admissions. The New York Times, p. Al.

Wygant v. Jackson Board of Education, 476 US 267 (1986). 